\title{
Dialética do sabor: alimentação, ecologia e vida cotidiana em comunidades ribeirinhas da Ilha de Ituqui, Baixo Amazonas, Pará
}

\author{
Rui Sérgio Sereni Murrieta \\ Laboratório de Estudos Evolutivos Humanos - Departamento de Biologial \\ Instituto de Biociências/USP
}

RESUMO: Poucas dimensões da vida humana são mais profundamente conectadas com a sobrevivência básica e, ao mesmo tempo, com elementos social e simbolicamente construídos, do que a alimentação. Este trabalho apresenta e analisa os dados sobre os processos de escolhas alimentares entre os habitantes da Ilha de Ituqui, Baixo Amazonas, Pará. A dieta na Ilha de Ituqui é dominada pela clássica combinação amazônica: farinha e peixe. É observável o esforço de diversificação alimentar e ao mesmo tempo a busca de contemporização com as continuidades do dia-a-dia e construções sociais de classe que orientam os processos de escolha e de consumo de alimentos cotidiano. Mesmo assim, não existe uma correlação positiva entre os alimentos de grande status social e aqueles que formam a base do consumo. Somado a isso, grande parte das representações alimentares parece apresentar um caráter - que não é necessariamente discursivo - bastante flexível e facilmente instrumentalizado nas mediações de contradições entre diferentes domínios sócio-políticos, os quais incluem tanto aspectos da micropolítica doméstica de casas e comunidades, quanto contextos mais abrangentes das economias políticas regional/nacional e transnacional. Assim, forças potenciais de mudança na lógica interna das estruturas habituais e dos sistemas socioculturais locais são acomodadas e negociadas. Concluindo, a forma como elaboramos e decodificamos nossa experiência física, bem como as nossas necessidades biológicas, cria uma relação dialética com nossos desejos sociais e estruturas habituais que só poderá ser resolvida (e compreendida!) quando as condições contextuais no momento da ação forem contempladas.

PALAVRAS-CHAVE: alimentação, caboclos, Amazônia, babitus, ecologia. 
Rui S. S. Murrieta. Dialética do Sabor: alimentaÇão, eCologia e Vida Cotidiana

\section{Introdução}

Seria difícil pensar em outro aspecto da vida humana mais profundamente conectado com a sobrevivência básica e, ao mesmo tempo, com elementos social e simbolicamente construídos do que a alimentação. Conseqüentemente, não há dimensão da vida social humana que incorpore melhor as contradições do processo cotidiano de tomada de decisão. É exatamente esta qualidade dos hábitos e escolhas alimentares em incorporar, acomodar e intensificar os conflitos implícitos entre o que é biologicamente necessário, socialmente desejado, ecologicamente possível e historicamente assimilado que será o tópico desta discussão.

$\mathrm{Na}$ Amazônia, os estudos sobre escolhas e hábitos alimentares entre as populações nativas ainda estão na sua primeira infância e largamente dominados por uma dicotomia simplista representada de um lado pelos estudos de abordagem sociocultural e, do outro, pelos de abordagens econômica e ecológica (Murrieta, 1998; 2000). No que se refere especificamente às populações campesinas "tradicionais" da Amazônia, ou caboclas, o nosso conhecimento sobre hábitos alimentares é ainda mais precário. As poucas etnografias existentes seguem a dicotomia referida acima, enfatizando aspectos sócio-estruturais e simbólicos dos sistemas de restrições alimentares (Motta-Maués \& Maués, 1980; Maués, 1990; Motta-Maués, 1993), ou, mais exclusivamente, aspectos econômicos e ecológicos (Begossi, 1992; Begossi \& Braga, 1992; Chibnik, 1994; Murrieta, 1994; Murrieta et al., 1999; Siqueira, 1997) e seus impactos nutricionais e epidemiológicos (Giugliano et al., 1981; 1984; Rocha et al., 1993; Silva et al., 1995).

Um dos aspectos que tem aflorado a partir destes estudos é a grande diversidade de estratégias de captura, produção e consumo alimentar em sociedades humanas amazônicas. Conseqüentemente, a principal questão que nos vem à cabeça é como motivações sociais diferenciamse de acordo com os padrões ecológicos, as diferentes formas de 
envolvimento com o mercado, a assimilação de novos padrões de consumo e as estruturas do cotidiano. Em face deste quadro, avaliações mais profundas dos processos históricos subjacentes às relações das sociedades nativas da Amazônia com o meio ambiente físico, com o mercado e com as mudanças político-econômicas da região tornaramse obrigatórias (Murrieta, 1994; 1998; 2000; Santos \& Coimbra, 1994; 1998; Siqueira, 1997).

Resumindo, existem poucos dados sobre as motivações das escolhas e hábitos alimentares, bem como suas implicações nutricionais, que possam nos levar a esquemas exploratórios mais abrangentes sobre os elementos socioculturais e biológicos que os motivam e estruturam. No rastro dessas preocupações, defendo a hipótese de que os processos de escolhas alimentares são o resultado da interação dialética entre as estruturas habituais do cotidiano, os ciclos ecológicos dos recursos naturais, a dinâmica político-econômica dos mercados locais e regionais e as representações de classe e preferências individuais. No entanto, a resolução prática deste processo repousa nas condições contextuais do momento da tomada de decisão, numa combinação de condições materiais, lógica estrutural cotidiana e preferências sociais.

Este artigo apresenta e analisa os dados sobre processos de escolhas alimentares observados entre os habitantes da Ilha de Ituqui, no Baixo Amazonas, Pará. Pretendo também demonstrar a inter-relação e a causalidade mútua dos fatores sociais, econômicos e biológicos que caracterizam este processo. Também, quero destacar o caráter complementar deste trabalho em relação ao artigo que eu consideraria a primeira parte desta trilogia, também publicada na Revista de Antropologia da USP (Murrieta, 1998), e a última parte que tratará exclusivamente sobre alimentação e desenvolvimento na Amazônia. Tendo em vista a complementaridade deste trabalho em relação ao artigo referido, mas, ao mesmo tempo, a necessidade de manter uma certa independência analítica, introduzi trechos do trabalho anterior (devidamente indicados no corpo do texto pela referência e numeração de página). Com tal 
Rui S. S. Murrieta. Dialética do Sabor: alimentaÇão, eCologia e Vida Cotidiana

artifício, acredito ter mantido a densidade e integridade dos meus argumentos, dispensando a necessidade de uma consulta continua ao artigo de 1998, que poderia ser cansativa ao leitor. Levando em conta o esclarecimento acima, retomo as seguintes perguntas de pesquisa:

1. Quais são as motivações e critérios que agem sobre os processos de uso e escolha cotidianos de alimentos dos indivíduos e das famílias de Ituqui?

2. Como essas motivações e critérios são combinados e acomodados com as demandas das práticas cotidianas e do consumo alimentar?

\section{A Ilha de Ituqui: ecologia, economia e história}

A Ilha de Ituqui está localizada nas várzeas do Baixo Amazonas, $30 \mathrm{~km}$ a leste da cidade de Santarém (Figura 1). O meio ambiente local é caracterizado por inundações sazonais e ecozonas diversificadas. A estação seca, também chamada de verão, prolonga-se de agosto a dezembro. Durante este período, a precipitação diminui drasticamente, juntamente com os níveis dos rios e lagos, deixando a maior parte dos campos e restingas descobertas. As restingas são os terrenos mais altos da várzea, que se estendem sobre as margens dos rios e lagos, enquanto que os campos inundados são savanas que margeiam os poucos lagos perenes da região. A estação chuvosa estende-se de dezembro a maio, inundando a maior parte da área das terras de várzea e atingindo o seu pico no mês de junho. Ao sul, a Ilha de Ituqui é banhada pelo Paraná do Ituqui, um dos inúmeros canais do Amazonas, onde as áreas de restingas são mais altas e numerosas e, ao norte, pelo canal principal do rio Amazonas.

Os habitantes da Ilha de Ituqui, assim como a maior parte dos habitantes da várzea do Amazonas, são tradicionalmente chamados de caboclos, ribeirinhos ou varzeeiros. O termo caboclo é utilizado neste artigo para denominar a parte da população camponesa amazônica originada na miscigenação das antigas populações indígenas da várzea 
Revista de Antropologia, São Paulo, USP, 2001, v. 44 nº 2.

do Amazonas com os colonizadores europeus e, em menor número, com os escravos africanos, durante os séculos XVIII e XIX (Lima, 1992; Bunker, 1984; Galvão, 1955; Moran, 1974; Nugent, 1993; Parker, 1985a; 1985b; Ross, 1978; Wagley, 1988). Não pretendo dar a este termo nenhum caráter de identidade étnica, mas apenas usufruir da sua utilidade analítica.

Os moradores de Ituqui estão distribuídos em oito comunidades às margens da Ilha e áreas vizinhas. As comunidades são: Aracampina, Santana, São José, São Raimundo, São Benedito, Fé em Deus, Conceição e Nova Vista. A pesquisa foi centralizada, principalmente, em Aracampina e São Benedito. Em 1994 a população destas oito comunidades contava com quase dois mil habitantes no período do verão.

A maioria dos habitantes da ilha são pequenos proprietários e suas famílias têm residido na área desde o final do século XIX e começo do século XX. Até o fim da primeira metade do século XX, alguns dos antigos moradores tiveram certo grau de envolvimento com a extração de borracha nas áreas vizinhas de terra firme e com o cultivo de cacau na várzea. Entretanto, estas atividades parecem ter sido completamente eclipsadas pelo cultivo da juta, após a Segunda Guerra Mundial (ver também em Furtado, 1994; Gentil, 1988; McGrath et al., 1993a; 1993b; Winklerprins, 1999).

Até o início da década de 1980, a agricultura era a principal atividade econômica da região, caracterizada pelo cultivo da juta e de culturas de rápido crescimento como algumas variedades de mandioca, feijão, milho e melancia. Hoje, o trabalho agrícola é desenvolvido por toda a família, mas a maior parte da responsabilidade repousa nos ombros das mulheres. As roças de mandioca e campos de feijão localizam-se normalmente em áreas vizinhas ou pelo menos de fácil acesso para as unidades domésticas. Nas redondezas das unidades domésticas podese observar grande número de plantas medicinais, decorativas e alimentares que formam o quintal e o jardim, dispostas em torno da casa ou em canteiros suspensos (jiraus). 
Rui S. S. Murrieta. Dialética do Sabor: alimentaÇão, eCologia e Vida Cotidiana

Outras atividades, como a pesca e a caça de espécies comerciais (por exemplo peixe-boi, jacaré e pirarucu), chegaram a desempenhar um papel importante na economia local. Entretanto, depois do colapso do mercado da juta no início da década de 1980, a pesca tornou-se a principal fonte de alimento e renda para uma boa parte da população da ilha (ver também McGrath et al., 1993a, 1993b; McGrath, 1994; Smith, 1981). A pesca desempenha um papel central na economia dos moradores de Ituqui. Concentrada nos lagos interiores da ilha e no principal canal do Amazonas, a pesca estende-se por todo o ano, aumentando ou diminuindo de intensidade de acordo com a estação. No verão, os pescadores concentram-se nos lagos perenes do interior e ao longo das margens do Amazonas. As capturas são feitas com redes malhadeiras, tarrafas, arpão, anzol e linha. Os grandes bagres, menos consumidos domesticamente, são capturados no rio Amazonas, principalmente, para a comercialização, nos meses de agosto e setembro.

É no verão que começa a temporada da pesca do Pirarucu. Apesar de pouco consumido localmente e sem ocupar um lugar de destaque nas preferências individuais, a captura desse peixe parece vir acompanhada de uma mística bastante particular e tem desempenhado um papel crítico na construção de uma identidade local (Murrieta, 1998; 2000).

A pecuária apresenta outras importantes variáveis na economia e sociedade locais. A maioria dos rebanhos, formados por variedades de zebus e algumas cabeças de búfalos, varia de tamanho podendo chegar até a mais de uma centena. Os rebanhos desempenham um papel minimizador do impacto e riscos da pesca e da agricultura, assim como representam uma segurança financeira para os tempos difíceis (idem). Sua manutenção é difícil na várzea, principalmente nos tempos de inverno e cheia, quando os pequenos proprietários precisam cortar e carregar grandes quantidades de capim (canarana) para alimentar os animais amontoados nas marombas (currais elevados), ou pagar alguém para fazê-lo (idem). 
Revista de Antropologia, São Paulo, USP, 2001, v. 44 nº 2.

\section{Algumas considerações metodológicas}

Inicialmente, concentrei a pesquisa em algumas unidades domésticas de duas comunidades da Ilha de Ituqui - Aracampina e São Benedito - onde já haviam sido realizados alguns estudos exploratórios. As unidades de análise deste estudo foram o indivíduo e a unidade doméstica. Para esta escolha, parti do pressuposto de que o indivíduo é a unidade fundamental para compreensão de qualquer ação social e a unidade doméstica a "principal arena para expressões de papéis sexuais e etários, de parentesco e socialização, e cooperação econômica (...) onde cultura é mediada e transformada em ação" (Netting, 1993: 59 apud Murrieta, 1998: 113; ver também Netting et al., 1984; Wilk, 1989).

Para melhor compreensão dos critérios usados por indivíduos na escolha da sua alimentação, e entendimento dos aspectos contextuais do processo com suas variações e regularidade, conduzi entrevistas não-estruturadas e semi-estruturadas (Bernard, 1994). O objetivo preliminar das entrevistas não-estruturadas e semi-estruturadas era compor uma lista abrangente de alimentos, assim como os aspectos e critérios mais comuns para o sistema local de classificação (tais como origem, significado social, tabus alimentares, etc.). Defini uma amostra central de 16 indivíduos, nove homens e sete mulheres, que forneceram a maior parte das informações aqui apresentadas. Os principais critérios para a escolha da amostra foram gênero (homens e mulheres) e idade (subadulto e adulto). Resumindo, procurei produzir um tamanho amostral no qual os indivíduos de ambos os sexos e diferentes faixas etárias, mas principalmente adultos, estivessem proporcionalmente representados.

$\mathrm{Na}$ análise de contribuição calórica e protéica dos alimentos referidos no texto, utilizei a técnica de recordatório de 24 horas $(24$ hour foodrecall). Esta resume-se a entrevistas estruturadas sobre os tipos, quantidade e processamento dos alimentos consumidos na unidade 
Rui S. S. Murrieta. Dialética do Sabor: alimentaÇão, eCologia e Vida Cotidiana

doméstica no dia anterior. Este levantamento estendeu-se por sete dias contínuos em quatro unidades domésticas em São Benedito e oito em Aracampina. Os valores dietéticos foram obtidos da tabela de composição química de alimentos brasileiros desenvolvida por Franco (1987) e calculados usando o software Excel, versão 2000 (para maiores detalhes sobre esta metodologia veja Murrieta, 1998 ou Murrieta et al., 1999).

Também observei uma família em uma das comunidades por sete semanas durante o verão (setembro-outubro) de 1995. As técnicas utilizadas para esta fase do trabalho também foram observação participante e entrevistas informais, não-estruturadas e semi-estruturadas (Bernard, 1994). As entrevistas foram registradas em cassetes e cadernos de campo. Ao longo do trabalho mantive um diário de campo para narrar eventos e expressar sentimentos, impressões e idéias em uma forma mais livre e subjetiva.

As características da vida doméstica descritas neste artigo foram resultado, principalmente, das minhas experiências com a família de um casal em São Benedito, Sávio (50) e Marta (53). Durante a minha estadia na casa destes, procurei acompanhar a rotina diária de homens e mulheres, assim como de crianças e adolescentes. Entretanto, exemplos de outras famílias de São Benedito e da Ilha, principalmente de Aracampina, serão freqüentemente utilizados.

Procurei também registrar detalhadamente os comportamentos referentes à produção e captura de itens alimentares que tinham um papel mais significativo nos sistemas de alimentação local. Somado a isto, investiguei a interação e o fluxo de alimentos de indivíduos e unidades domésticas com sistemas sócio-econômicos e políticos mais abrangentes (por exemplo mercados regionais, estilos de vida urbano, tendências políticas e econômicas recentes).

Como medida de proteção à privacidade dos meus informantes, não utilizei os seus verdadeiros nomes, mas pseudônimos, como poderá ser observado no texto abaixo. 
Revista de Antropologia, São Paulo, USP, 2001, v. 44 nº 2.

\section{A comunidade de São Benedito e a Ilha de Ituqui}

Como a maioria dos habitantes da Ilha de Ituqui, os residentes de São Benedito são pequenos proprietários. Alguns de seus ancestrais parecem ter residido na Ilha pelo menos desde o final do século XIX. Contatos próximos foram e são mantidos com outras comunidades, especialmente as vizinhas São José e São Raimundo. Na verdade, não havia grandes distinções espaciais entre essas comunidades, tornando-as uma unidade contínua de ocupação (ver Figura 1). Durante a estação seca, a beira do rio liga estas comunidades, tornando as visitas eventos fáceis e constantes. Apesar dos quase imperceptíveis limites geográficos entre as comunidades, havia uma espécie de cuidado com as fronteiras e a identidade da comunidade.

O núcleo da vida "comunitária" em São Benedito estava concentrado ao redor de uma pequena capela de madeira, da escola e da sede, um tipo de salão (também chamado de barracão). Todo o complexo é concentrado numa área cercada de mais ou menos $100 \mathrm{~m}^{2}$, a única área reconhecida por todos em São Benedito como propriedade coletiva da comunidade.

Normalmente, as unidades domésticas têm uma população mais permanente representada pelos chefes de família e seus descendentes mais jovens. Entretanto, não é raro acharmos unidades domésticas multifamiliares, com casais jovens e velhos sob o mesmo teto. Como foi mencionado acima, a maior parte das minhas observações foi feita entre a família de Sávio e Marta. Em 1995, eles viviam em uma casa com seis de seus nove filhos: os gêmeos Peto e Mônica (11), Pipa (15), Bela (18), Beto (21) e Elison (22). A filha mais velha de Sávio casarase havia um ano e mudara-se para uma vila (colônia) na Terra Firme. Augusto, o filho mais velho de Sávio, também casara-se e vivia na própria comunidade com sua esposa, Lana (29), e seu primeiro bebê.

Uma conexão muito importante existia entre a unidade doméstica de Sávio com a unidade doméstica vizinha, pertencente a Seu Didi (80) 
Rui S. S. Murrieta. Dialética do Sabor: alimentaÇão, eCologia e Vida Cotidiana

e Dona Joana (74) -- patriarca e matriarca da família de Sávio. Seu Didi nasceu em São Benedito, assim como seu pai. Na primeira vez em que encontrei Seu Didi, em 1994, ele tinha oitenta anos e Dona Joana, 73. Viviam em uma pequena casa de madeira pintada de azul, localizada na porção mais central da comunidade, próxima à escola, à capela e à sede. Seu filho mais novo, Cássio, ainda solteiro, vivia com eles. Duas netas também viviam com o velho casal, Iara (18) e Rosa (11). Três outras unidades domésticas tornaram-se rapidamente parte das minhas visitas sistemáticas na comunidade: a irmã de Sávio, Antonieta (47), casada com o irmão de Marta, Gabriel (50). Vivendo do outro lado do cavado, que passava pela casa de Augusto, estavam Dona Isaura (58), Seu Dinho (68) e os seus filhos. Rio acima, aproximadamente a $1 \mathrm{Km}$ da casa de Augusto, vivia um velho casal, Seu Osmarino e Dona Luba. Viviam sozinhos em uma casa velha onde criaram seus dez filhos. Apenas um dos filhos, Paca, ainda vivia na comunidade, em uma casa vizinha àquela de seus pais. O resto da família mudara-se para Santarém ou para outras cidades do país.

\section{Escolhas e hábitos alimentares}

Não haveria como duvidar do fato que os dois alimentos centrais da dieta dos moradores de Ituqui são o pescado e a farinha de mandioca. Outros produtos como o arroz, a carne de gado, as massas e o feijão, apesar de desempenharem papéis cada vez mais relevantes no consumo das unidades domésticas, ainda orbitam em torno dos dois produtos principais mencionados acima. Outros alimentos são relegados à categoria de "não-comida" (ou não-refeição), como por exemplo os temperos e verduras, complementos de merendas e outros itens de consumo ocasional. Em Ituqui, o almoço, que acontece por volta das $12 \mathrm{~h} 00$, e o jantar, por volta das $19 \mathrm{~h} 00$, são as principais refeições do dia e é quando grande parte da ritualização do consumo acontece. Lanches e merendas acontecem no meio da manhã e no meio da tarde. 
Apesar da diferença de status entre as refeições principais, ocasião em que é servida "comida de verdade", e os lanches e merendas, que normalmente se resumem a café com açúcar e bolachas crackers, como veremos abaixo, café e açúcar podem representar uma parte significativa do consumo total de energia, assim como um elemento vital na manutenção das rotinas de trabalho e outras relações sociais.

\section{Café, temperos e verduras}

As refeições matinais na casa de Sávio e Marta eram normalmente compostas de uma xícara de café extremamente açucarado, acompanhada às vezes por bolachas de água e sal ou torradas joelhinho (feitas de pão francês). Esta forte combinação de caloria concentrada (açúcar) e cafeína parecia ser capaz de manter as pessoas por longas horas de trabalho com pouca ou nenhuma comida sólida, especialmente levando em consideração que a primeira refeição significativa do dia acontecia normalmente ao meio-dia. Esta norma era quebrada quando, às vezes, Sávio e os filhos chegavam do trabalho no meio da manhã e pediam uma "merenda mais reforçada", que Marta improvisava com restos do jantar ou com ovos de galinha e farinha de mandioca. É importante lembrar aqui que a maior parte das tarefas de subsistência era realizada durante as horas menos quentes do dia, principalmente de manhã. Entre meio-dia e as três da tarde a temperatura chegava a níveis quase insuportáveis tornando qualquer atividade física bem mais penosa. É fácil ver a conecção entre a ingestão de grandes quantidades de cafeína e açúcar e a manutenção de longas horas de trabalho e de uma certa estrutura do cotidiano. O papel do açúcar e do café é bem conhecido na expansão do sistema colonial e da sociedade burguesa na Europa (Braudel, 1981; Mintz, 1985; Schvelbusch, 1992). Esta poderosa combinação dietética resolveu vários problemas concretos da reprodução da estrutura do trabalho industrial no século XIX e XX, assim como viabilizou a economia monocultora das colônias (Mintz, 1979; 
Rui S. S. Murrieta. Dialética do Sabor: alimentaÇão, eCologia e Vida Cotidiana

1985; Schvelbush, 1992). Tal importância pode ser explicada em parte pelo efeito estimulante da cafeína, somado a uma temporária perda de apetite, que combinados a uma dose de pura caloria concentrada de açúcar possibilita que os trabalhadores encarem longas horas de trabalho sem muita ou nenhuma alimentação (Schvelbush, 1992). Em Ituqui, as necessidades estruturais do trabalho cotidiano nas unidades domésticas podem ser somadas à sonolência que toma conta do corpo nas horas mais quentes do dia. É difícil lembrar quantas vezes nós nos consolamos com quantidades revigorantes de café com açúcar durante uma manhã de trabalho na roça, uma expedição de pesca ao lago ou uma simples visita durante o início da tarde a uma família da comunidade.

A contribuição do açúcar para o consumo de energia por unidade doméstica ilustra bem esta importância. O açúcar é a segunda fonte não-animal de caloria mais consumida nas unidades domésticas estudadas, computando $11 \%$ do total de energia consumida em Aracampina e 11.5\% em São Benedito (ver Tabela 1). Durante a estação seca Aracampina e São Benedito tiveram, respectivamente, 9.2\% e $10.1 \%$ de energia proveniente do açúcar, e $12.7 \%$ e $12.8 \%$ durante a estação chuvosa (ver Tabela 2). O que chama mais a atenção nos dados acima é o aumento do consumo durante a estação chuvosa, que pode estar relacionado a maior instabilidade do consumo de outras fontes de energia mais comuns. De qualquer maneira, a simples mistura do café com açúcar parecia resolver alguns problemas bastante básicos da reprodução do trabalho cotidiano, que poderiam resultar em mais horas de procura de alimento ou de trabalho pago para garantir uma performance minimamente satisfatória. Além deste óbvio benefício material, o cafezinho tornou-se um importante elemento na socialização em Ituqui, como na sociedade brasileira em geral. Servir o cafezinho a uma visita ou simplesmente temperar uma conversa de meio de tarde era um gesto obrigatório no código de boas maneiras locais. Não era incomum ouvir alguém depreciar a hospitalidade de um vizinho ou conhecido usando apenas a falta do cafezinho ("nem cafezinho me serviram!"). 
Revista de Antropologia, São Paulo, USP, 2001, v. 44 nº 2.

Temperos, verduras e frutas são também incluídos na categoria periférica de não-comida. Uma das características da dieta ribeirinha na região de Santarém é a quase ausência do consumo de verduras e legumes. Apesar da presença obrigatória dos girais, estes são quase que exclusivamente utilizados para a produção de pequenas quantidades de temperos e ervas. Os temperos mais comuns na dieta local são a cebolinha, chicória, coentro, pimentinha e alfavaca. Pimentões e couves são também cultivados e utilizados na preparação de alimentos, mas aproximadamente nas mesmas quantidades discretas dos temperos. Tomates e cebolas são menos freqüentes nas roças e jiraus pelas dificuldades de adaptação destas culturas ao clima, sendo normalmente comprados no mercado de Santarém.

A idéia central do uso de temperos e verduras é o melhoramento do sabor da comida. Aqui é necessário uma diferenciação entre os conceitos de gosto e de sabor. Apesar de não haver uma diferença real no uso coloquial destes conceitos, acreditamos que a sua diferenciação neste trabalho pode beneficiar a nossa compreensão dos processos de escolhas alimentares. Uma definição fisiológica direta do conceito de gosto se refere ao estímulo sensorial único da língua, em outras palavras do paladar. Enquanto o conceito de sabor se aplica a "um estágio do processo degustatório que inclui inputs de diferentes modalidades, por exemplo do olfato" (Rolls, 1997: 46). Assim, sabor pode ser considerado uma representação do gosto mais avançada e talvez mais refinada. Pode-se então dizer que a experiência degustatória é melhor representada como "um contínuo de sensações do que por categorias discretas" (Macbeth \& Lawry, 1997: 2). Obviamente, não queremos restringir os conceitos de gosto e de sabor a uma experiência puramente sensorial, especialmente levando em consideração que o objetivo primário deste trabalho não é identificar processos puramente fisiológicos, mas sim a interação dos últimos com esferas socioculturais e econômicas. A utilização de um conceito fisiológico é apenas o primeiro passo para abordar o "gosto" como uma experiência unificada, a qual inclui representações culturais, 
Rui S. S. Murrieta. Dialética do Sabor: alimentaÇão, eCologia e Vida Cotidiana

a estrutura da vida cotidiana e as esferas sócio-econômicas. Assim, pretendo usar a diferenciação entre gosto e sabor apenas quando for útil para a discussão do papel do último nas motivações de escolhas e preferência alimentares.

Normalmente, a utilização de temperos é largamente negligenciada na literatura acadêmica e, quando mencionada, procura-se destacar o seu papel puramente fisiológico. Conseqüentemente, o papel de temperos e condimentos no aumento da diversificação do sabor e de uma resultante quebra na repetitividade e monotonia da dieta tem sido subestimado. Esse tema era uma constante na maioria das conversas sobre alimentação com minhas informantes. Por exemplo, Marta (56), e Antonieta (43), vizinhas e parentas com quem coletei grande parte das informações sobre a culinária local, costumavam se referir ao uso de temperos e condimentos como uma maneira de fazer a comida "menos chata". Esta experiência sensorial da "mesma" comida cotidiana quando temperada e enriquecida cria uma forma de diversificação da dieta, ou pelo menos da experiência degustatória per se (Rozin, 1987).

No que se refere ao consumo de frutas, a sua existência depende em grande parte do ciclo das cheias. As espécies nativas como o ingá (Inga sp.) são altamente sazonais e normalmente têm períodos de frutificação muito breves. Algumas castanhas também são consumidas, mas em quantidades mínimas. No caso das últimas, os moradores de Ituqui ainda têm de enfrentar a competição acirrada de pássaros e morcegos que consomem as nozes antes que o ouriço caia no chão. Frutas domésticas são mais produtivas do que a maior parte das espécies nativas, mas são também mais vulneráveis ao estresse das cheias. Após uma grande enchente é comum ver pomares inteiros de bananeiras, abacateiros, goiabeiras, mangueiras e mamoeiros completamente arruinados (Murrieta, 2000). Assim, o ciclo das águas do Amazonas faz que o consumo de frutas seja pouco e esporádico. As poucas vezes que presenciei um consumo significativo de frutas 
foi durante uma dessas frutificações relâmpagos ou por causa de uma compra, troca ou presente feito durante uma visita à Santarém ou à vizinha terra firme.

Frutas são consumidas principalmente como merendas ocasionais na própria casa ou em coletas oportunísticas durante uma breve expedição ao lago, no retorno da roça ou visitando alguma casa da vizinhança. Acredito que a coleta casual de frutas seja mais relevante para as crianças e adolescentes do que para os adultos. É comum observar crianças de idades variadas coletando goiabas, castanhas e jenipapos a caminho de casa. Até mesmo frutas cultivadas em jardins e quintais, que são consideradas propriedades privadas, são coletadas por crianças, desta forma sem provocar maiores conflitos. Aparentemente, a idéia de propriedade, que é tão acalentada por vários moradores de Ituqui e pode causar longos conflitos e querelas, parece relaxar um pouco quando os protagonistas são as crianças locais. No geral, ninguém parece dar grande atenção para estas coletas casuais de frutas.

\section{Mandioca, habitus e classe}

Apesar da importância da farinha de mandioca, na várzea o seu cultivo encontra grandes obstáculos, representados principalmente pelo caráter imprevisível das cheias e a pouca resistência da mandioca a inundações (Dufour, 1995a; 1995b). Alguns autores argumentam que, no passado, as populações ameríndias resolviam este problema desenvolvendo o uso múltiplo e concomitante de várias ecozonas (Denevan, 1996; Moran, 1990; Roosevelt, 1980), em outras palavras, explorando tanto as áreas de várzea quanto as de terra firme, para garantir o abastecimento tanto de pescado quando de mandioca ao longo do ano em ambas as áreas. Esta estratégia ainda é utilizada pelos moradores de Ituqui que compram ou alugam terrenos nas áreas próximas de terra firme para o plantio de mandioca. Aqueles moradores que não têm acesso às áreas de terra firme e vivem em áreas inundáveis têm que contar com trabalhos 
Rui S. S. Murrieta. Dialética do Sabor: alimentaÇão, eCologia e Vida Cotidiana

esporádicos na cidade e nas comunidades próximas, e os magros recursos naturais disponíveis no inverno.

Para os habitantes de Ituqui, assim como para a maior parte das populações rurais da Amazônia, a farinha de mandioca tem sido a fonte local mais confiável de energia. Em São Benedito e Aracampina, a farinha e outros derivados da mandioca somam $25.2 \%$ e $34.0 \%$ do total de energia consumida respectivamente, podendo ser considerados a maior fonte de energia de origem não-animal da dieta local (ver Tabela 1). Durante a estação seca a farinha e outros produtos derivados da mandioca somaram 22.9\% do consumo de energia em São Benedito e $34.0 \%$ em Aracampina. Já para o consumo na estação chuvosa a contribuição dos derivados da mandioca foi de $27.6 \%$ em São Benedito, e $28.6 \%$ em Aracampina (ver Tabela 2). O aumento do consumo de produtos de mandioca em São Benedito está intimamente ligado à colheita deste produto nos meses de fevereiro e março. Enquanto em Aracampina a maior parte da mandioca consumida, principalmente em forma de farinha, precisa ser comprada, devido a pouca quantidade de terra disponível para o seu cultivo e à subida mais precoce das águas nesta comunidade durante a enchente.

Entretanto, acredito que o papel da mandioca e derivados, principalmente a farinha, na dieta local vá mais além do que o "alimento de emergência" ou a "fonte segura de calorias". É primariamente um gosto adquirido, intimamente conectado às rotinas da vida cotidiana, às regularidades dos ciclos sociais e ecológicos, e a um certo sentido de lugar. É um habitus conforme conceituado por Pierre Bourdieu. Este último define habitus como um sistema de predisposições mantidos e reproduzidos por atores sociais; é, ao mesmo tempo, um conjunto de disposições transponíveis e a matriz de experiências passadas traduzidas em percepções, apreciações e práticas (Bourdieu, 1983a; 1983b; Murrieta, 1998).

Um dos elementos centrais no desenvolvimento do habitus é o sabor (e aqui nos referimos tanto ao fenômeno social quanto ao fisiológico, 
Revista de Antropologia, São Paulo, USP, 2001, v. 44 nº 2.

ver seção acima). Comecemos pelos aspectos mais primários do consumo da farinha. Vários dos meus informantes eram capazes de reconhecer a qualidade de farinhas baseados em aspectos específicos do sabor. Um dos tópicos constantes das nossas conversas com os moradores de Ituqui era sobre as qualidades da boa farinha. A textura e o gosto (paladar) são elementos centrais na boa farinha. Os informantes se referem a uma crocância característica da farinha bem processada, normalmente associada a um gosto agridoce e provavelmente causada pelos vestígios de ácido cianídrico deixados após o processamento. A coloração amarelada e o tamanho irregular dos "bagos" adicionam qualidade ao produto. A farinha "ruim" é reconhecida por um certo azedume e umidade típicos de uma "torração" incompleta. O cheiro também acusa o mau processamento. Uma das minhas informantes usava o termo "pitiú" para o cheiro da farinha mal torrada, que é usado normalmente para caracterizar o cheiro da carne de animais, principalmente do peixe. As pessoas falam com prazer da mistura de sensações que acompanham o consumo da farinha, que inicia com a experiência do já mencionado gosto agridoce e crocante, e termina com uma sensação de completa saciedade; para não falar de empanzinamento, causado pela expansão do produto durante a sua digestão.

Esta preferência característica pela farinha pode ser observada nas suas formas de consumo cotidiano. Além de fartamente ingerida durante o almoço e o jantar, sempre acompanhando algum tipo de proteína animal, a farinha é consumida em pequenas quantidades de forma aleatória durante a passagem pela cozinha. Nessas ocasiões, crianças e adolescentes passam rapidamente pela cozinha e enfiam a mão no vasilhame (uma lata de leite Ninho ou algum vasilhame puído de plástico) de farinha agarrando pequenos punhados e arremessando-os à boca. Farinha também é misturada ao café com açúcar, sendo a farinha de tapioca particularmente preferida para esta mistura. Aliás, o consumo de farinha de tapioca com café pode ser observado em toda a região amazônica, inclusive nas grandes cidades. O gosto por tal mistura é facilmente 
Rui S. S. Murrieta. Dialética do Sabor: alimentaÇão, eCologia e Vida Cotidiana

compreendido quando se leva em consideração o efeito de saciedade, estímulo e energia que uma pessoa experimenta após ingerir esta combinação concentrada de cafeína, amido (fécula) e sacarose.

Vários tipos de mingaus são preparados tendo a farinha como ingrediente básico. A maior parte destes mingaus é voltada para a alimentação de crianças, idosos e enfermos. Entretanto, muitas pessoas desenvolvem um certo gosto por estes mingaus, incorporando-os nas refeições e merendas diárias. Crianças, por exemplo, são alimentadas nos primeiros meses de vida, como um complemento à amamentação, com um mingau, chamado carimã, feito de farinha e massa de mandioca (tapioca) finamente peneiradas, açúcar e sal. Entre as famílias em melhor situação financeira, leite em natura ou em pó é adicionado.

Um outro tipo de mingau largamente consumido é o chibé. A preparação do chibé é relativamente simples e bastante similar à do carimã. A farinha é levemente peneirada e encharcada com água morna, e colocada para cozinhar em água fervendo com um pouco de sal. Óleo de cozinha e um pouco de leite podem ser adicionados para melhorar o sabor. O resultado é uma substância quente e densa que, segundo alguns, tem grandes qualidades curativas.

No campo das representações, a farinha desempenha um papel paradoxal como um marcador de classe. Entre as classes média e média alta do Brasil e também da Amazônia, o consumo diário de farinha é normalmente substituído, pelo menos em grande parte, pelo da sua versão tostada, a farofa. No imaginário urbano desses grupos, a farinha é tratada como uma espécie de gosto da necessidade desenvolvido pela população mais empobrecida, que não tem outra alternativa alimentar. $\mathrm{Na}$ Amazônia, pode-se dizer que apesar de generalizado, o consumo diário e em grande quantidade da farinha (principalmente como elemento central da refeição) é profundamente conectado às classes urbanas mais pobres e a um estilo de vida rural. Estes são vistos no imaginário regional das elites urbanas, que de certa forma se torna o imaginário dominante, como inferiores, derrogatórios e indesejáveis. É importante lembrar que 
este imaginário está historicamente associado às condições das populações indígenas e mestiças (caboclas) da Amazônia; exatamente aquelas que representam as camadas urbanas e rurais marginalizadas. Alguns dos informantes se apropriaram ambiguamente desses valores. De um lado, a farinha incorpora o cotidiano doméstico, um gosto adquirido e um elemento vital dos repertórios dietéticos e de subsistência e, do outro, as condições desprivilegiadas daqueles que vivem na base da pirâmide sócio-econômica. O chibé é um exemplo interessante neste sistema de representações. É comum, na região Amazônica, os pobres urbanos e rurais serem chamados de uma maneira derrogatória de "papa-chibé", como uma forma de se referir às suas origens sociais "mais humildes" (mesmo que essas condições hajam mudado no presente), caracterizadas pelo alto consumo de farinha. Entretanto, notei que a desvalorização discursiva da farinha pelos meus informantes era mais um display público de uma pretensa e relativa superioridade social, bem como uma estratégia política, neste caso de confronto e diferenciação, do que uma desconexão real com o alimento. Era óbvio para qualquer um que acompanhasse a vida cotidiana em Ituqui, mesmo daqueles que subestimassem a importância da farinha, que o papel que a última desempenhava, tanto na economia quanto em esferas socioculturais, era bem mais relevante. Para ilustrar mais eficientemente o argumento acima, insiro aqui a transcrição originalmente publicada na primeira parte desta trilogia em 1998:

São Benedito, 7/1995

A discussão da roda foi sobre o consumo de farinha. Seu Didi disse que farinha é mais comida do pessoal do sítio (interior rural) do que de gente da cidade. Gabriel disse que o pessoal mais civilizado "comia menos farinha". Seu Didi tomou a palavra e protestou, dizendo que se o pessoal do sítio tivesse onde comprar, eles comprariam menos farinha e mais arroz porque a farinha estava mais cara. João Paca interveio na conversa dizendo que o pessoal de fora (sulistas) não comia farinha porque eles não tinham farinha "que preste". Lá a farinha "é muito rala, que se colocar no vento voa tudo". Seu Didi referiu-se em tom jocoso ao fato de Joca ter dito que na casa dele quando 
Rui S. S. Murrieta. Dialética do Sabor: alimentaÇão, eCologia e Vida Cotidiana

não tinha farinha "não prestava". Seu Didi usou a conversa para me lembrar sobre a minha pergunta sobre quem era "caboco" - "olha aî", dizia, apontando para Joca. O último em tom desafiante disse, “eu sou caboco mesmo!”. Falou que gostava de farinha até no café, principalmente a farinha de tapioca. "Gosto quando vem emboladinha que senta", finalizou Joca. A chacota de Seu Didi aumentou mais ainda quando Joca falou que não havia nada como chibé (mingau de farinha). O primeiro interrompeu aos risos exclamando: “olha aí o papa-chibé”! (Murrieta, 1998)

Um dos aspectos mais interessantes da conversa acima é o fato de que Seu Didi tinha o hábito de adicionar farinha de tapioca ao café da manhã e costumava ficar irritado quando faltava a "sua tapioca" (esta informação me foi dada pela própria esposa e confirmada por ele mais tarde). Este paradoxo entre o discurso público (desvalorizando socialmente a farinha) e o privado (reconhecendo a dependência e importância da farinha) expõe a dinâmica de conflito e acomodação destes níveis diferenciados, mas completamente interligados. Podese dizer, sem nenhuma hesitação, que todos os participantes da conversação acima baseiam grande parte do seu consumo alimentar na farinha de mandioca e derivados. Assim, parece-me que a elaboração pública discursiva sobre o consumo da farinha e sua "natural" ligação com a condição social do "caboclo" é muito mais um display de hostilidades pessoais e agendas familiares de ascensão social que um traço concreto das práticas cotidianas.

O conflito entre o discurso público e a prática privada ficou muito mais óbvio para mim quando, no verão de 1995, o preço da farinha alcançou e até ultrapassou o preço do arroz. Mesmo neste momento, em que a compra da farinha tornou-se uma desvantagem, as pessoas não pararam de consumi-la. Fiquei ainda mais intrigado com este comportamento quando descobri que, a esta altura do ano, a grande maioria dos moradores de São Benedito não tinha mais a farinha produzida domesticamente e estava comprando todo o consumo da casa. Decidi perguntar diretamente a Sávio porque as pessoas não substituíam completamente a farinha por arroz já que o preço do último estava 
Revista de Antropologia, São Paulo, USP, 2001, v. 44 nº 2.

compatível e até mais vantajoso que o da farinha. Ele me olhou um tanto surpreso e disse: "Ah! Tem que ter alguma farinha ou então o pessoal fica brabo".

\section{Carne, arroz e feijão: a cidade, o sítio e outras metáforas de classe}

Um outro aspecto importante dos processos de escolha alimentar em Ituqui é a dicotomia entre o que é a comida da cidade e a comida do "sítio" (interior ou área rural). Já foi bastante discutido na literatura sociológica brasileira o papel do dualismo básico representado pela cidade e o campo (sítio) na formação da sociedade nacional (ou talvez fosse mais apropriado dizer das "sociedades" nacionais). De certa forma, podemos dizer que foi este dualismo que forjou a dialética social do imaginário brasileiro, produzindo uma suposta dicotomia das "realidades" brasileiras entre a tradição e a modernidade, o conservadorismo e o progresso, o privado e o público (Freire, 1933; DaMatta, 1987). Hoje compreendemos que tal divisão é muito mais fluida e negociável e seus elementos mais concomitantes e manipuláveis do que se pensava. $\mathrm{Na}$ Amazônia a ambigüidade dessas oposições parece ter sido ainda mais cristalizada no imaginário popular em função da situação sócio-econômica periférica da região e dos sistemas de valores relacionados à primeira. Da mesma forma que a fluidez, a negociação e a manipulação dessas categorias em formas discursivas e não-discursivas parecem também ter alcançado níveis bem sofisticados nas práticas cotidianas.

De uma maneira geral, as representações dos contextos rurais amazônicos parecem ter variado entre a idéia de um "vazio" de civilização, em que o homem seria parte da paisagem "natural", e da imagem da "fronteira" sócio-econômica, aprisionada na expansão e no desenvolvimento inevitáveis do capitalismo (Nugent, 1993; Slater, 1994). Caboclos e índios têm estado no epicentro dessas representações. Eles têm sido historicamente relacionados a uma série de imagens que 
Rui S. S. Murrieta. Dialética do Sabor: alimentaÇão, eCologia e Vida Cotidiana

combina idéias de estagnação e atraso sócio-econômicos, conservadorismo e uma certa "naturalização" romantizada (Nugent, 1993; Lima, 1992; Motta-Maués, 1989). Em direta oposição a essas imagens, estão as da modernidade que caracterizam a cidade como lócus de progresso, desenvolvimento e dinamismo. Não é de surpreender que esta mesma dicotomia impregnou as práticas, atitudes e discursos do cotidiano da maioria das sociedades amazônicas.

Como no caso da farinha, outros alimentos não escaparam a este dualismo. Dentre os inúmeros itens que compõem o repertório dietético "urbano", podemos dar algum destaque para o arroz, pelo menos no caso de Ituqui. O arroz está representado localmente como um alimento urbano, geralmente conectado à classe média, ocupando o outro extremo do espectro em relação à farinha, que é representada como uma comida do "sítio", incorporada de certa forma ao "ser caboclo" (Murrieta, 1998: 124). Assim, "a combinação dos dois ou sua exclusão, mesmo quando pressionada por fatores econômicos, traz consigo importantes metáforas de identidade, classe e ascensão social" (idem). Aqui, é preciso introduzir uma breve contextualização histórica da produção deste imaginário. Até recentemente, o acesso a produtos industrializados e outros alimentos importados como carnes e cereais enlatados, óleo de cozinha, leite em pó, manteiga e trigo, era um luxo que poucas pessoas podiam ter. As dificuldades de transporte, conservação e estocagem, somadas ao controle dos meios de troca pelo sistema de aviamento, privaram, e de certa forma ainda destituem, uma parcela significativa da população amazônica do acesso a esses produtos. Apesar da explosão demográfica urbana e a erosão do sistema de aviamento na região nas últimas décadas, a obtenção de produtos alimentícios "importados" e industrializados ainda está diretamente ligada à proximidade de centros urbanos e acesso a dinheiro. Assim, a presença de produtos "importados" como o arroz e até enlatados simples podem ser um evento esporádico na mesa de várias famílias rurais da Amazônia. 
Revista de Antropologia, São Paulo, USP, 2001, v. 44 nº 2.

A família de Sávio e seus afins pode ser inserida numa categoria mais privilegiada economicamente. A combinação de uma pequena, mas estável renda salarial (principalmente aposentadorias); uma rede sólida de reciprocidades que inclui amigos e parentes em outras comunidades e na cidade de Santarém, e a proximidade da cidade de Santarém garantiam à família de Sávio o acesso sistemático a alimentos importados de outras regiões. Apesar da importância da farinha e do peixe ser inquestionável, a presença do arroz, do macarrão e de outros importados não eram eventos raros nas refeições na casa de Sávio. Em algumas unidades domésticas que tinham renda maior, o consumo destes produtos era ainda mais significativo. Dentre estes produtos, o arroz era o item de maior constância nas mesas de Ituqui. $\mathrm{O}$ aumento do consumo de arroz parecia estar ligado principalmente aos baixos preços que o produto alcançou nos mercados locais (em torno de $\mathrm{R} \$ 1,00$ o quilo).

Uma mudança bem-vinda ao repetitivo menu de farinha e peixe, o consumo de arroz era visto principalmente como uma maneira de enriquecer a diversidade do repertório alimentar do que de substituir os alimentos "tradicionais." De outro lado, eu também observei que a crescente presença de arroz nas refeições da família nuclear e extensa de Sávio, principalmente na casa de Seu Didi e Lana, sinalizava algumas das ambições sociais e a auto-imagem cultivada da família. De fato, a proximidade e a identificação ideológica de vários habitantes de São Benedito com as classes regionais mais abastadas, representadas principalmente pelos fazendeiros e classes médias urbanas, contrastavam com a maior parte das famílias de outras comunidades de Ituqui. Assim, pode-se dizer que o arroz, carregando um pouco da mística da alimentação urbana e de elite, servia, como diria Roland Barthes (1997: 25), como um "sinal" e um "meio" para enfatizar, ou apropriar-se de, um estilo de vida considerado socialmente superior e desejado. Seria assim um mecanismo discreto para estabelecer algumas distinções de classe (mesmo que materialmente estas fossem pouco aparentes) entre a família extensa de Sávio e os outros habitantes de Ituqui. 
Rui S. S. Murrieta. Dialética do Sabor: alimentaÇão, eCologia e Vida Cotidiana

Apesar do aumento do consumo de arroz, bem como de outros cereais, a contribuição destes para o consumo calórico e protéico é relativamente discreta. Cereais (arroz, milho e trigo) contribuíam apenas com $8.2 \%$ e 10.5\% da energia consumida em São Benedito e Aracampina (Murrieta, 2000), durante a semana do levantamento, e a maior parte era proveniente do arroz.

O milho era voltado principalmente para a alimentação de galinhas e patos. O pouco consumo de milho observado por nós foi para a preparação de mingaus como complementos das refeições principais. Estes eram preparados com uma rica combinação de açúcar, leite (quando disponível) e castanhas nativas. O trigo era mais utilizado para a fritura de peixe e, mais raramente, nos bolinhos e pastéis feitos com açúcar e sal consumidos como substitutos das bolachas de água e sal. Uma certa variação sazonal podia ser observada no consumo de cereais, principalmente o arroz, apontando para um decréscimo durante a estação chuvosa em ambas as comunidades. Esta variação é facilmente associável com a diminuição da renda doméstica nos meses de enchente e, para algumas famílias, principalmente em São Benedito, com a colheita da mandioca e a produção de farinha nos meses de fevereiro e março (idem).

O pão com manteiga também era fortemente associado à vida urbana. O pão é obtido na cidade de Santarém e consumido principalmente de duas formas: o clássico pão francês e sua alternativa nortista, o "massa fina" (de massa mais densa e sem a superfície torrada e crocante do francês). Torradas feitas com pão francês, também chamadas "joelhinho", são compradas em grande quantidade e particularmente apreciadas devido ao seu baixo preço e alta durabilidade (o que num clima tropical úmido é uma qualidade bastante apreciada). Apesar da "manteiga" (na verdade margarina) ser considerada um acompanhamento obrigatório do pão, era sem dúvida um item mais raro na mesa. Normalmente esses dois alimentos não duravam mais que dois ou três dias, pois eram consumidos rapidamente pela família nuclear e pelas crianças da família 
Revista de Antropologia, São Paulo, USP, 2001, v. 44 nº 2.

extensa, que sempre eram chamadas ou simplesmente "apareciam", para uma "merenda". Lembro de uma tarde de verão quando conversava à mesa com Bela, Marta e Peto. Este último levantou-se atendendo a um chamado discreto do seu primo que acenava do umbral da porta da cozinha. Bela perguntou para onde ele ia, já sabendo que uma de suas tias havia chegado de uma viagem de abastecimento a Santarém. Ele disse que ia com seu primo visitar esta mesma tia. Bela não demorou a provocá-lo dizendo num meio tom de caçoada e despeito: “Ah, vai comê pão, hein!’”.

Um outro alimento que carrega consigo algumas interessantes conotações de identidade é o feijão. Até mais que o arroz, o feijão é uma quebra na monotonia da dieta básica. A produção local de feijão restringia-se à variedade "manteiguinha", um feijão branco de sabor mais suave que o popular "mulato". O último é importado em grande parte do sul e sudeste do país e pode chegar a preços proibitivos, o que restringe em muito seu consumo local. Porém, é o sabor denso e forte deste último que agrada aos habitantes de Ituqui. Já a variedade manteiguinha é consumida principalmente como sopas e ensopados durante o pico da colheita e os meses seguintes.

Também considerado como uma comida de cidade, ou que pelo menos carrega a mesma mística, o feijão ocupa um lugar especial na preferência dietética das populações descendentes de nordestinos. Os nordestinos são chamados localmente de arigós. O termo carrega uma carga relativamente pejorativa em relação aos caboclos paraenses. Aliás, as distinções entre os grupos de descendência nordestina recente e os chamados ribeirinhos (ou caboclos “tradicionais") já foi notada por vários cientistas sociais, dentre estes se destaca Stephen Nugent (1993). Nugent, na sua etnografia sobre a cidade de Santarém, procura mostrar que a "ramificação" arigó da cultura cabocla apresenta distinções que se estendem da prosódia até a estrutura social. Mesmo as áreas preferidas para a ocupação e os padrões de subsistência apresentam distinções perceptíveis a um olhar mais arguto. Entre essas diferenças, está o 
Rui S. S. Murrieta. Dialética do Sabor: alimentaÇão, eCologia e Vida Cotidiana

cultivo e o consumo "tradicional” do feijão. Em função dessas distinções, estabeleceu-se na região de Santarém uma divisão que se poderia dizer geográfica, onde caboclos ribeirinhos ocupam preferencialmente a várzea e os arigós a terra firme, chamada de colônia. De certa forma a preferência pela terra firme permite aos caboclos-arigós o cultivo de espécies e a reprodução de vários hábitos alimentares que seriam difíceis de acontecer na várzea. O consumo de feijão mulato, bem como a sua forma de preparo, cria uma distinção entre estes dois galhos da chamada cultura cabocla (talvez devêssemos dizer “culturas”) e traz dúvidas sobre a representação homogênea e generalista que inúmeros pesquisadores e desenvolvimentistas abraçam no que se refere ao campesinato histórico da Amazônia.

Esta conecção do feijão com a cultura arigó ficou mais óbvia quando descobri que as poucas vezes em que eu comi feijão mulato na casa de Sávio e Marta foi porque Lana o havia preparado. Lana havia nascido e crescido em Belterra, uma cidade conhecida pela grande colonização nordestina desde o início do século. O próprio pai de Lana é cearense. A diferenciação entre arigós e ribeirinhos era discretamente ressaltada pelo próprio marido, Augusto, que gostava de brincar com o filho, de pouco mais de um ano, chamando-o de “arigozinho.” Não há dúvida, que o fato de Lana ser professora e diretora assalariada da escola de São Benedito tornava o acesso à compra de itens mais caros como feijão mais freqüente. Mas ela não hesitava em dizer que o "pessoal da várzea não dava muito valor ao feijão" e que se fosse por ela teria feijão em casa "todos os dias".

Mais até que o arroz e o feijão, a carne de gado é considerada pela maior parte dos nossos informantes como o alimento da elite par excellence. O próprio uso exclusivo do termo carne para denominar a carne de gado já é um indicador do lugar especial desse alimento no imaginário local. Observei em vários momentos sociais o uso e o consumo de determinados alimentos, como a carne de gado, "que incorporaram simbolicamente a abundância, o poder e o prestígio das camadas sócio-econômicas mais 
altas, neste caso, principalmente, os fazendeiros e criadores locais" (Murrieta, 1998: 123-4). A representação do gado como um elemento de ascensão social apresenta-se, muitas vezes, como uma forma de capital simbólico (ver Bourdieu, 1983a apud Murrieta, 1998), ou de representação e associação de uma condição de classe. Os moradores de Ituqui percebem qualquer elemento conectado à atividade da pecuária como um indicador de uma condição sócio-econômica desejável, apesar de dificilmente alcançável. Resumindo, “comer, ter e oferecer carne (de gado) em determinados momentos sociais (festas comunitárias, datas familiares importantes, etc.) podiam significar a apropriação simbólica do prestígio, do direito ou, simplesmente, do desejo de ascensão social" (Murrieta, 1998: 123; ver também Murrieta, 2000).

\section{Peixe, tabus e proteína}

O pescado é, sem dúvida alguma, a maior e mais confiável fonte de proteína na Ilha de Ituqui, assim como na Amazônia de maneira geral (Murrieta, 1998). Entretanto, a variedade de espécies consumidas oferece uma certa diversidade de opções e sabores, conseqüentemente, de preferências, que desafiam a simplificação do consumo do pescado em uma única categoria. O consumo de peixe é determinado em grande parte pelas variações sazonais ecológicas, pela habilidade do pescador e pela pura sorte. Apesar destes fatores, um conjunto relativamente extenso de escolhas está freqüentemente disponível, principalmente após boas capturas. As pessoas não hesitam em demonstrar suas preferências individuais por este ou aquele peixe quando a ocasião permite.

Duas categorias gerais compõem o sistema de classificação local de peixes: o peixe liso (ou peixe de pele) e o peixe de escama. Ambas as categorias são apreciadas por diferentes razões. Peixes lisos são normalmente apreciados pelo sabor "forte" e estrutura fibrosa da carne. Enquanto os peixes de escama são caracterizados como tendo um sabor mais "fraco", leve e suave, sendo assim mais "digeríveis", mas não 
Rui S. S. Murrieta. Dialética do Sabor: alimentaÇão, eCologia e Vida Cotidiana

necessariamente mais saborosos (às vezes, é exatamente o oposto). Mas nem todas as espécies de peixe são facilmente inseridas nestas duas categorias mais gerais. O comportamento, a dieta, a cor, o cheiro e a aparência são também importantes critérios no processo de classificação e escolha. Por exemplo, vários tipos de peixe de escama são vistos de maneira diferenciada e acabam incorporando características ambíguas em relação a outros peixes da mesma categoria, exatamente por causa da combinação de comportamento, dieta e ecologia do animal. Marta e Sávio me disseram, certa vez, que alguns peixes de escamas são diferentes porque são "fortes" como, por exemplo, a piranha (Murrieta, 1998). Muitas pessoas encaram o consumo de piranha com certa repulsa devido ao fato de ela se alimentar de carne de animais vivos e mortos. Por outro lado, o sabor "forte" e a carne "sangrenta" da piranha qualificam-na como um alimento com "muitas vitaminas" (idem; Maués \& Motta-Maués, 1978). É importante destacar aqui que muitos dos nossos informantes incluem as categorias nutricionais de vitaminas e minerais numa mesma categoria classificatória chamada de maneira geral "vitaminas". Apesar do uso do termo, falar de vitaminas refere-se muito mais a aspectos visíveis relacionados à boa saúde e força física de um indivíduo, ou a definições abstratas como substância e energia (aparentemente emprestados de uma fonte hipocrática/galênica), do que a algum conceito científico contemporâneo.

A incorporação deste tipo de conhecimento convencional científico em categorias culturais locais parece ser um fenômeno geral na Amazônia. Um exemplo relativamente popular é o ferro. Várias pessoas em Ituqui, assim como em outras partes da Amazônia, fazem referência constante ao alto conteúdo de ferro de vários alimentos regionais como a piranha e o açaí (Euterpe oleracea). Como já foi referido acima, o ferro, sendo este uma "vitamina", pelo menos na percepção local, é associado com conceitos de "força" e "substância" (Murrieta, 1998: 123).

Para justificar este tipo de caracterização de alguns alimentos, principalmente do pescado, alguns dos meus informantes (Marta e 
Revista de Antropologia, São Paulo, USP, 2001, v. 44 nº 2.

Sávio, por exemplo) faziam referência ao comportamento do animal consumido, à sensação de saciedade e empanzinamento vivenciada após o consumo, à densidade do alimento (principalmente no que se refere à quantidade e qualidade da gordura) e à coloração (normalmente cores escuras e brilhantes como violeta, púrpura, vermelho, cinza e marrons). Por exemplo, Marta disse, em uma de nossas conversas, que o acari, como a piranha (Murrieta 1998: 123), era um peixe de "força e energia, porque era difícil de morrer. Tem de dá uma pancada forte, senão ele não morre". Assim, acredito que pelo menos no caso de Ituqui a apropriação de categorias científicas ocidentais é muito mais formal que substancial. De certa forma, a categoria mantém a sua qualidade humoral e a sua essência "nativa". O que é mais contrastante com este tipo de elaboração local sobre o ferro é o fato de que médicos e nutricionistas que trabalham na região expressam grande preocupação com um suposto baixo consumo de ferro (ou talvez baixa absorção), principalmente devido à grande dependência do pescado. Em geral, a carne de peixe apresenta baixos índices de ferro. No entanto, é ainda muito cedo para fazer qualquer generalização sobre alguma forma de deficiência crônica de ferro devido aos poucos dados sobre consumo alimentar em populações ribeirinhas (Murrieta, 1998; Murrieta et al., 1999).

Este tipo de divergência conceitual atraiu a minha atenção para um outro aspecto do consumo de pescado em Ituqui. Já foi observado que as tabelas de composição de alimentos são baseadas em análises feitas nas partes mais carnudas e densas que apresentam menos espinhas (Giugliano et al., 1978), expressando assim o nosso viés urbano pelo chamado filé. No entanto, após longas observações durante as refeições cotidianas em São Benedito ficou claro que as pessoas consumiam todo o peixe, deixando apenas as espinhas maiores, partes do crânio e cauda e alguns poucos pedaços de pele. A cabeça do peixe é partida e a gordura e carne internas são consumidas avidamente, as membranas em torno dos olhos são chupadas, indicando um aproveitamento quase completo do animal. Algumas espécies, como o curimatá, são particularmente 
Rui S. S. Murrieta. Dialética do Sabor: alimentaÇão, eCologia e Vida Cotidiana

apreciadas exatamente pelo acúmulo de gordura que o peixe apresenta após os meses de cheia. Era comum ouvir Marta comentar, durante a limpeza e preparação do peixe, que "esse tá é muito gordo".

Muitas vezes havia uma certa preferência por determinadas partes do peixe que se refletia na ordenação e no acesso dos membros da casa à refeição. Como na maior parte das sociedades camponesas latino-americanas (Messer, 1991), em São Benedito, os homens tinham acesso ao alimento servido durante a refeição primeiro que as mulheres, o que parece produzir variações nas preferências individuais bastante interessantes. Por exemplo, na família de Sávio encontramos uma certa preferência generalizada pela cabeça do acari. Todos falam com prazer e indisfarçável apetite do "tutano" - uma concentração de carne e gordura da cabeça do animal. Apesar disso, era claro que as caudas e as partes mais espinhosas do peixe eram deixadas para as mulheres e meninas, que depois de um certo tempo pareciam desenvolver um "gosto" por estas partes. Dona Joana, a mãe de Sávio, falou certa vez com um tom quase de ingenuidade sobre a sua preferência pela cauda do peixe e dizia que achava que havia se acostumado a consumi-la.

Algumas dessas preferências eram apropriadas pelos membros da unidade doméstica para intensificar ou relaxar conflitos interindividuais, criando assim uma espécie de gastropolítica da vida cotidiana (Appadurai, 1981). A minha assistente de campo, que foi criada numa comunidade na margem esquerda do Amazonas, contou-me que quando o seu avô começava alguma disputa doméstica com a sua avó, ele costumava pegar todas as cabeças de acari durante o jantar para si, sabendo que a esposa só comia a cabeça do acari, como uma maneira de aborrecê-la.

Essa preferência peculiar pelo acari é ainda mais aparente durante uma piracaia. A piracaia é um tipo de churrasco improvisado próximo aos pontos de pesca, normalmente pelos próprios pescadores. Um pequeno fogão é cavado numa depressão rasa no chão e é coberto com 
Revista de Antropologia, São Paulo, USP, 2001, v. 44 nº 2.

varetas, onde os peixes são colocados. A preparação é bastante simples, resumindo-se a uma limpeza rápida com água e limão (usado para tirar o "pitiú") e remoção das entranhas. Nessas ocasiões o acari era particularmente preferido. Em parte esta preferência era devida ao fato de não haver necessidade de remoção das entranhas do acari, podendo ser assado sem maiores preocupações, e ao sabor forte e gorduroso da carne, acentuado pela fogo, tornando este peixe perfeito para a piracaia. Sávio e seu filho mais novo, Peto, comentaram certa vez que "o acari é o peixe da piracaia".

A diferenciação entre os peixes de escamas e os de pele (lisos) é ainda mais crítica para o sistema local de restrições alimentares: a reima. A reima é um sistema classificatório de restrições e proibições alimentares aplicados a pessoas em estados físicos e sociais de liminaridade (MottaMaúes \& Maués, 1980; Maués \& Motta-Maués, 1978; Motta-Maués, 1993; Murrieta, 1998). O significado de liminaridade utilizado neste artigo pode ser entendido como estados de representação ritual e simbólica de transição ou passagem (Motta-Maués, 1993; Murrieta, 1998). A tradição da reima remete-se à medicina medieval de inspiração hipocrática-galênica que foi transplantada para a América portuguesa (Rodrigues, 2000). Dentre as principais situações consideradas de liminaridade estão as enfermidades, a menstruação e o pós-parto. A reima é caracterizada por oposições binárias entre alimentos perigosos (reimosos) ou não-perigosos (não-reimosos) (Murrieta, 1998). As restrições da primeira não são nem homogêneas nem consensuais entre os informantes; não existe, pois, um único sistema, mas vários deles que diferem de acordo com gênero, idade, estado liminar e experiência pessoal. Essa elasticidade da reima tornou-se clara quando Peto ficou doente com algum tipo de infecção urinária. Ele sentia dor quando urinava, percebendo algumas vezes a presença de sangue na urina, e por alguns dias teve febre. Marta estava muito preocupada, mas mesmo assim decidiu esperar e tratá-lo com ervas locais (chá de uriza). Um certo dia Marta e Alison surpreenderam Peto comendo acari: 
São Benedito, 13/9/1995

Peto comeu acari ontem no jantar. Marta e Alison, o irmão mais velho, ralharam com ele dizendo que ele não devia estar comendo acari. Peto se defendeu dizendo que acari não era reimoso. "É reimoso, sim!" disse Alison firmemente. Hoje, eu perguntei a Alison se acari era peixe de pele ou peixe de escama, e ele respondeu que era de escama. Logo depois eu perguntei se ele era reimoso, ele respondeu um pouco hesitante: "Para algumas pessoas era, né?".

Os principais alimentos considerados reimosos são os "peixes lisos" ou de "pele" (surubim, piaba, filhote, mapará, pirarara, etc.), alguns peixes de "escamas" (pescada, curimatã, tucunaré amarelo, jatauarana, acari, etc.), tipos de caça (peixe-boi, capivara, jacaré, tracajá, tartaruga, etc.) e algumas frutas consideradas "ácidas" (laranja, limão, cupuaçu, taperebá) (Murrieta, 1998: 121). Como o exemplo do ferro que utilizamos mais acima, a caracterização de frutas ácidas também se apropria de elementos do repertório médico convencional, neste caso o conceito de acidez, que é misturado com os elementos supostamente "folk" da reima (idem). Sistemas similares têm sido observados e descritos entre outras populações caboclas da região por Begossi \& Braga(1992), Fleming-Moran (1990), Galvão (1955), Lima (1992), Motta-Maués \& Maués (1980), Maués (1990), Motta-Maués (1993), Wagley (1988).

O equilíbrio do corpo e do espírito é o principal alvo das proibições da reima. O pós-parto e a menstruação são representados como momentos de maior fragilidade e vulnerabilidade para mulheres. É quando a ingestão de um alimento reimoso pode prejudicar não apenas a mulher, mas aqueles que estão ligados física e emocionalmente a ela. Uma das duas parteiras da comunidade de Aracampina disse-nos em certa ocasião: "teve mulher aqui na comunidade que já comeu pescada no tempo do resguardo e botô sangue do umbigo da criança”" (Murrieta, 1998: 122).

No caso da menstruação, as restrições permanecem até o final do ciclo, enquanto no pós-parto elas podem variar de sete a quarenta dias, 
seguindo vários estágios proibitivos (Murrieta, 1998). Durante a menstruação, cuidados específicos são voltados ao consumo de frutas ácidas, como a melancia e o abacaxi e, é claro, peixes de pele. Apesar da gradativa erosão desses sistemas, os cuidados com a menstruação são também conectados à relação entre as pessoas e as entidades "sobrenaturais" do rio e das matas. No caso da várzea Amazônica, o rio e a terra representam a dicotomia mais abrangente no imaginário regional, sendo o primeiro fonte tanto de mal quanto de bem e o ser que melhor representa esta metáfora é o boto (ver Galvão, 1955; MottaMaués, 1993; Maués, 1990; 1995; Slater, 1994; Wagley, 1988 para maiores detalhes).

Um alimento não é reimoso apenas em função das suas características (textura e sabor), mas também no que se refere à natureza do comportamento e do contexto específico do animal que foi a fonte do alimento consumido. Voltando ao exemplo da piranha, o mesmo acontece, pois ela é de certa forma considerada poluída uma vez que "come carne de bicho morto", e assim pode "apodrecer" a carne do paciente (Murrieta 1998: 123). Como já vimos, a consideração oposta também pode ocorrer. É só lembrar a idéia, destacada por Marta, de que a piranha era rica em ferro porque era um peixe "forte" e, como o acari, demorava a morrer.

\section{Discussão e conclusão}

Os dados apresentados neste artigo sobre escolhas alimentares em Ituqui sugerem um processo bem mais complexo daqueles representados na literatura acadêmica até o momento. Neste processo, fatores "limitantes", ecológicos e econômicos, são traduzidos localmente em um número de variáveis restritas, em que opções e preferências movimentam-se, e são (também!) articuladas emocional e culturalmente (Murrieta, 1998).

Em outras palavras, as escolhas alimentares são resultado de uma relação multidirecional, na qual os elementos impactados acabam 
Rui S. S. Murrieta. Dialética do Sabor: alimentaÇão, eCologia e Vida Cotidiana

tornando-se os impactantes. Em termos estratégicos, eles podem ser manipulados consciente ou inconscientemente. Entretanto, no contexto das percepções cognitivas e do domínio do babitus, o principal tradutor torna-se a continuidade do dia a dia e a previsibilidade do que já é conhecido. É exatamente na fricção e na acomodação de idéias dominantes de classe e de gostos adquiridos, e na busca pela diversificação, que vamos encontrar a gênese dos processos de escolhas descritos acima (Murrieta, 1998).

No nível mais básico desses processos nós temos a experiência degustadora per se, claramente ilustrada pelo uso de temperos e estimulantes. Aqui, algumas das sensações originadas na ingestão de alguns temperos e estimulantes estão intimamente conectadas à estrutura de certas esferas do cotidiano e características específicas da dieta. Por exemplo, o papel do café com açúcar parece reforçar e reproduzir uma dada rotina de trabalho e interações sociais, e ainda é uma fonte fácil de energia para os períodos mais críticos do trabalho cotidiano e para o calendário sazonal. Embora, em hipótese nenhuma nós tenhamos negligenciado a busca por fontes confiáveis de energia como parte integrante das preocupações cotidianas das pessoas, acreditamos que o que orienta a maior parte das situações subjacentes aos processos de escolha alimentar é a dialética intrínseca entre monotonia e diversificação dietética. Assim, o uso dos temperos pode ser relacionado concomitantemente à estrutura monótona da dieta e a um certo gosto adquirido, uma maneira segura de criar uma experiência familiar durante o processo degustatório ao mesmo tempo em que se saboreia uma certa diversidade superficial. Pode-se imaginar a importância dessa função em dietas caracterizadas por uma estrutura monótona como a de Ituqui. Assim, textura, cheiro, aparência e espaço social convergem em uma experiência integrada que combina de maneira dialética sensações, estímulos e desejos.

Aqui é importante introduzir um aspecto crítico dos processos de procura e escolhas alimentares de seres humanos: o dilema onívoro. De uma perspectiva puramente evolutiva, o dilema onívoro seria o 
Revista de Antropologia, São Paulo, USP, 2001, v. 44 nº 2.

"medo e a curiosidade sobre novos alimentos (...) representados no indivíduo pelo desejo pela familiaridade de alimentos, como um indicador de alimentos seguros, e um desejo oposto por variedade e reação contra a monotonia das dietas" (Rozin, 1987:197-8). Acredito que é este dilema básico que impregna as estruturas cotidianas, criando os desejos por alimentos específicos, os quais estão por sua vez associados a ciclos ecológicos e ocasiões sociais.

Um outro aspecto crítico das escolhas alimentares é a busca por status. O consumo de carne vermelha desempenha um papel privilegiado nessa busca. A carne de gado, ao mesmo tempo em que quebra a repetitividade da estrutura dietética, incorpora uma condição social, um determinado status adquirido ou desejado por aqueles que a consomem. A associação da carne com situações de display social ou simples afirmação pode ser facilmente compreendida pela conexão histórica que a pecuária e o consumo sistemático de carne sempre tiveram com as elites econômicas amazônicas. Aqui, em níveis diferenciados, observa-se o uso e consumo de alimentos como marcadores de status (ou pelo menos do desejo pelo último) e situações. Nessa dialética do cotidiano, distinções sociais são definidas, condições enfatizadas e preferências negociadas. Novamente, é o pensamento de Roland Barthes que resume essa idéia de maneira mais eficiente: "comida serve como um sinal não apenas para temas, mas também para situações” (1997: 25). Motivação similar apesar de bem mais discreta pode ser observada na incorporação mais rotineira do arroz (Murrieta, 1998).

Do outro lado do espectro, mas seguindo a mesma lógica de representação de classe e de estruturação do consumo cotidiano, nós encontraremos a farinha. Os derivados da mandioca, principalmente a farinha, desempenham exatamente o papel oposto da carne entre os moradores de Ituqui. Sua importância como fonte de energia é inegável, como pode ser observado nos valores obtidos para o consumo doméstico. Entretanto, o papel da farinha no sistema de representações pode ser considerado no mínimo paradoxal, especialmente se contrastarmos sua 
Rui S. S. Murrieta. Dialética do Sabor: alimentaÇão, eCologia e Vida Cotidiana

importância nutricional com a aparente "desvalorização" social que a acompanha. Podemos facilmente especular aqui que tal desvalorização é o resultado lógico da subestimação e da trivialização das práticas e de identidades nativas no imaginário regional. Mas este mesmo paradoxo expõe um aspecto da cultura camponesa amazônica constantemente subestimado: a resistência. $\mathrm{O}$ sistema da mandioca (cultivo, consumo e representação) parece incorporar a contradição mais central da estruturação de classe e de poder na Amazônia, ou seja, um sistema de subsistência nativo "invisível" que tem o papel mais crítico na sobrevivência social e biológica da população local. Ao mesmo tempo, o cultivo e o consumo da mandioca, dada a sua dependência dos recursos de natureza doméstica e familiar (e.g. mão de obra e conhecimento local), é uma prática que tem historicamente minimizado o poder de domínio e coerção das elites locais sobre o campesinato caboclo (Pace, 1998; Weinstein, 1991). Ao lado do papel do cultivo da mandioca como um discurso oculto da "resistência" camponesa, está o seu papel como elemento centralizador da estrutura habitual da dieta local. Em outras palavras: um gosto adquirido e estruturado, um habitus, o qual é manipulado silenciosamente como uma referência da identidade local (mesmo que derrogatória) e/ou uma posição de contradominação.

Finalmente, o sistema de restrições alimentares, a reima. É importante enfatizar aqui que não estou tentando explicar as origens históricas da reima, mas simplesmente o seu papel e impacto nos processos de escolha alimentar em Ituqui. Ficou claro para mim que, apesar das respostas relativamente diretas e seguras sobre o que é perigoso comer e o que não é, as práticas subjacentes parecem ser bastante negociáveis e dependentes do contexto e do momento. Porém, um padrão começa a delinear-se. A reima impacta principalmente as mulheres, não apenas restringindo o seu acesso a determinados alimentos, mas também a sua mobilidade espacial. Se de certa forma tais restrições aumentam o controle sobre o corpo feminino e o que é consumido, também uma rede de cuidados e atenções é estabelecida entre as mulheres, diminuindo 
Revista de Antropologia, São Paulo, USP, 2001, v. 44 nº 2.

assim as responsabilidades cotidianas de cuidado com a prole e manutenção do trabalho doméstico. A rotinização dessas restrições também estrutura preferências e aversões, enfatizando as divisões de gênero, criando ao mesmo tempo mecanismos que aliviam a estrutura cotidiana de trabalho e a responsabilidade sobre a produção de alimentos.

Concluindo, acredito que as motivações que impulsionam o comportamento humano e suas possíveis e prováveis implicações parecem convergir numa unidade de ação e de experiências individuais acumuladas, na qual causa e efeito se confundem. Nesse processo, visões aparentemente contraditórias são mediadas num único esquema cultural. Vários autores (Anderson, 1996; Clifford, 1988; Descola \& Palsson, 1993; Ingold, 1992; 1996) nos têm chamado atenção para o fato de que a compartimentalizacão da experiência humana, tanto física quanto social, é um subterfúgio analítico, perpetuado por uma tradição cartesiana, que se tornou completamente insatisfatória para a compreensão do caráter justaposto das nossas motivações, práticas e construções culturais do cotidiano.

A forma como elaboramos e decodificamos nossa experiência física assim como as nossas necessidades biológicas (se aceitarmos a idéia de determinadas inclinações biológicas humanas como produto da nossa evolução de primatas onívoros) cria uma relação dialética com nossos desejos sociais e estruturas habituais que só poderá ser resolvida quando as condições contextuais do momento da ação são contempladas.

Por último, grande parte das representações alimentares parece apresentar um caráter nem sempre discursivo bastante flexível, e facilmente instrumentalizado nas mediações de contradições entre diferentes domínios sócio-políticos. Tais domínios incluem tanto aspectos da micropolítica de unidades domésticas e comunidades como o de contextos mais abrangentes da política econômica regional/nacional e transnacional; acomodando ou intensificando forças potenciais de mudança na lógica interna dos sistemas socioculturais locais. 


\section{Agradecimentos}

Gostaria de agradecer em primeiro lugar aos moradores das comunidades de Aracampina e São Benedito pela sua colaboração voluntária e entusiasmo na realização desta pesquisa. Meus agradecimentos ao Dr. David McGrath e aos membros do Projeto Várzea, principalmente aos meus queridos assistentes, Perpétuo Socorro de Souza e Edimar Dantas pela sua inestimável colaboração em campo e em laboratório. A Darna Dufour, Terry McCabe, Walter Alves Neves, Antoinette Winklerprins, Cristina Adams, Jorge Pozzobon, Andréa Siqueira, Maria Sylvia e Benedito Nunes pelas suas críticas e sugestões. A Andréia Sanjad e Cris Sampaio pela revisão do texto. Ao Laboratório de Cartografia da Universidade do Wisconsin em Madison pelo mapa utilizado neste artigo. Ao apoio institucional e financeiro do convênio IPAM/WWF/ODA/UFPa. Quero também agradecer ao CNPq pelas bolsas de doutorado (Proc. 200337-2) concedidas ao autor durante a realização desta pesquisa e de desenvolvimento regional enquanto trabalhava no Museu Paraense Emílio Goeldi. À FAPESP pelo auxílio-pesquisa (Proc 96-7487/2) concedido através do Laboratório de Estudos Evolutivos Humanos (USP). Ao Departamento de Antropologia da Universidade do Colorado pelo apoio financeiro e institucional dos últimos anos. Meus agradecimentos especiais a um dos pareceristas anônimos da Revista de Antropologia da USP que destacou vários novos pontos para reflexão neste artigo. Por último, mas não menos importante, ao Museu Paraense Emílio Goeldi pelo apoio logístico e institucional durante a redação deste artigo. 
Revista de Antropologia, São Paulo, USP, 2001, v. 44 nº 2.

\section{Bibliografia}

ANDERSON, E.

1996 Ecologies of the Heart: Emotion, Belief and the Environment, Oxford, Oxford University Press.

APPADURAI, A.

1981 "Gastropolitics in Hindu South Asia", American Ethnologist, vol. 8: 494511.

BARTHES, R.

1997

"Toward a Psychology of Contemporary Food Consumption", in COUNIHAN, C. \& VAN ESTERIK, P. (eds.), Food and Culture, London, Routledge.

BEGOSSI, A.

1992

"Food Avoidances at Búzios Island (Brazil): their significance and relation to Folk Medicine", Journal of Ethnobiology, vol. 12(1): 117-39.

BEGOSSI, A. \& BRAGA, F. M.

1992

"Food Taboos and Folk Medicine among Fishermen from the Tocantins River (Brazil)", Amazoniana, vol. 12(1): 101-18.

BERNARD, R.

1994 Research Methods in Anthropology: Qualitative and Quantitative Approaches, Thousand Oaks, Sage Publications.

BOURDIEU, P.

1983a Distinctions: a Social Critique of the Judgment of Taste, Cambridge, Harvard University Press.

1983b "Esboço de uma teoria da prática", in ORTIZ, R. (org.), Bourdieu, São Paulo, Ática.

BRAUDEL, F.

Civilization and Capitalism, 15th-18th Century, New York, Harper \& Row. 
BUNKER, S.

1984

"Modes of Extraction, Unequal Exchange and the Progressive Underdevelopment of an Extreme Periphery: the Brazilian Amazon, 1600-1980", American Journal of Sociology, vol. 89(5): 1017-64.

CHIBNIK, M.

1994

"Risky Rivers: The Economics and Politics of Floodplain Farming in Amazonia", Tucson \& London, The University of Arizona Press.

CLIFFORD, J.

1988

Introduction: Partial Truths, in CLIFFORD, J. \& MARCUS, G. (eds.), Writing Culture: The Poetics and Politics of Ethnography, Berkeley, University of California Press, pp. 1-27.

CLIFFORD, J. \& MARCUS, G.

1988

"Writing Culture: The Poetics and Politics of Ethnography", Berkeley, University of California Press.

DAMATTA, R.

1987 A casa \& a rua, Rio de Janeiro, Guanabara.

DENEVAN, W. M.

1996

"A bluff model of riverine settlement in Prehistoric Amazonia", Annual Review of the Association of American Geographers, vol. 86(4): 654-1.

DESCOLA, P. \& PALSSON, G.

1993

Introduction, in Nature and Society: Anthropological Perspectives, London/ New York, Routledge.

DUFOUR, D.

1995 a

"A closer Look at the Nutritional Implications of Bitter Cassava Use", in SPONSEL, L. E. (ed.), Indigenous People and the Future of Amaronia: An Ecological Anthropology of an Endangered World, Tucson, Arizona Press.

$1995 b$

"Diet and Nutritional Status of Amazonian Peoples", in ROOSEVELT, Anna C. (ed.), Amazonian Indians from Pre-History to the Past, Tucson/ London, The University of Arizona Press. 
Revista de Antropologia, São Paulo, USP, 2001, v. 44 nº 2.

FLEMING-MORAN, M.

1992

"The Folk View of Natural Causation and Disease in Brazil and its Relation to Traditional curing Practice", Boletim do Museu Paraense Emílio Goeldi, Série Antropologia, vol. 8(1): 65-156.

FRANCO, G.

1987

Tabela de composição química dos alimentos, Rio de Janeiro/São Paulo, Livraria Atheneu.

FREIRE, G.

Casa-Grande \& senzala, São Paulo, Círculo do Livro.

FURTADO, L.

1994 Pescadores do Rio Amazonas: um estudo anthropológico da pesca ribeirinha numa área amazônica, Belém, Museu Paraense Emilio Goeldi.

GALVÃO, E.

1955 Santos e visagens, São Paulo, Companhia Editora National.

GENTIL, J

1988 "A juta na Agricultura de várzea na área de Santarém-Médio Amazonas", Boletim do Museu Paraense Emílio Goeldi, Série Antropologia, vol. 4(2): 11899.

GIUGLIANO, R., GIUGLIANO, L. G. \& SHRIMPTON, R.

1981 "Estudos nutricionais das populações da Amazônia, Várzea do Solimões", Acta Amazônica, vol. 11(4): 773-88.

GIUGLIANO, R., SHIRIMPTON, L., ARKOL, D., GIUGLIANO, L. G. \& PETRERE, $M$.

1978 "Diagnóstico da realidade alimentar e nutricional do Estado do Amazonas", Acta Amazônica, vol. 8(2): 5-53.

1984 "Estudos nutricionais das populações rurais da Amazônia II, Rio Negro", Acta Amazônica, vol. 14(3-4): 427-49.

1995

"A closer Look at the Nutritional Implications of Bitter Cassava Use", in SPONSEL, L. E. (ed.), Indigenous People and the Future of Amazonia: An Ecological Anthropology of an Endangered World, Tucson, Arizona Press. 
Rui S. S. Murrieta. Dialética do Sabor: alimentaÇão, eCologia e Vida Cotidiana

INGOLD, T.

1992

"Culture and the Perception of the Environment", in CROLL, E. \& PARKING (eds.), Bush Base, Forest Farm: Culture, Environment and Development, London, Routledge.

1996 "Hunting and Gathering Ways of Perceiving the Environment", in ELLEN, R. \& FUKUI, K. (eds.), Redefining Nature, London, Berg Publications.

LIMA, D. M.

The Social Category Caboclo: History, Social Organization, Identity and Outsider's Social Classification of the Rural Population of an Amazonian Region, Doctoral Dissertation, Cambridge, King's College.

MACBETH, H., LAWRY, S.

"Food preferences and taste: an introduction", in MACBETH, H. (ed.), Food Preferences and Taste, Oxford, Berghahn Books.

MAUÉS, R. H.

1990

A ilha encantada: medicina e xamanismo numa comunidade da pescadores, Belém, Gráfica e Editora Universitária/UFPa.

1995

Santos e festas: catolicismo e controle eclesiástico, Belém, Sejup.

MAUÉS, R. H. \& MOTTA-MAUÉS, A.

1978

"O modelo da Reima: representações alimentares em uma comunidade amazônica”, Anuário Antropológico 77, Rio de Janeiro, Tempo Brasileiro.

MCGRATH, D. (COORD.)

1994

"Projeto Várzea: Lake Reserve and Community Based Management of Varzea Resources", Ituqui, Brasil, ODA/WWF Proposal (WWFBR0604).

MCGRATH, D., CASTRO, F., FUTEMA, C., AMARAL, B. R., CALABRIA, J.

1993a "Manejo comunitário da pesca nos lagos de várzea do Baixo Amazonas", in FURTADO, L. G., LEITÃO, W., MELLO, A. F. de (eds.), Povos das águas: realidade e perspectivas na Amazoônia, Belém, Museu Paraense Emílio Goeldi, pp. 213-29.

1993b "Fisheries and the Evolution of Resources Management on the Lower Amazonian Varzea”, Human Ecology, vol. 21(2): 167-95. 
Revista de Antropologia, São Paulo, USP, 2001, v. 44 nº 2.

MESSER, E.

1991

"Getting'Through Three Meals a Day: Diet, Domesticity and Cash Income in a Mexican Community", in SHARMAN, A., THEOPHANO, J., CURTIS, K., MESSER, E. (eds.), Diet and Domestic Life in Society, Philadelphia, Temple University Press, pp. 205-33.

MINTZ, S.

1979

"Time, sugar and sweetness", Marxist Perspective, vol. 2(4): 56-73.

1985

Swetness and Power: the Place of Sugar in Modern History, New York, Penguin Books.

MORAN, E. F.

1974 "The Adaptive System of the Amazonian Caboclo", in WAGLEY, C. (ed.), Man in the Amazon, Gainsville, pp. 139-59.

1990 A ecologia bumana das populações da Amazônia, Rio de Janeiro, Vozes.

MOTTA-MAUÉS, M. A.

1989 "A questão étnica: índios, brancos, negros e caboclos", in Estudos e Problemas Amazônicos, Belém, Seduc/IDESP.

1993 "Trabalhadeiras" \& “Camarados": relações de gênero, simbolismo e ritualização numa comunidade amąônica, Belém, Editora Universitária UFPA.

MOT'TA-MAUÉS, M. A. \& MAUÉS, R. H.

1980 Hábitos e crenças alimentares numa comunidade de pesca, Belém, Falangola.

MURRIETA, R. S. S.

1994 Diet and Subsistence: changes in three caboclo populations on Marajó Island, Amazonia, Brazil, Unpuplished M.A. Thesis, Department of Anthropology, University of Colorado, $120 \mathrm{p}$.

1998 "O dilema do Papa-Chibé: consumo alimentar, nutrição e práticas de intervenção”, Revista de Antropologia, vol. 41(1): 97-150.

2000 The Dilemma of the Chibé-Eater: Food Choice, Ecology and Everyday Life among Peasant Communities in the Lower Amazon, Brazil, Unpublished Ph.D. Dissertation, Department of Anthropology, University of Colorado at Boulder, 220 p. 
Rui S. S. Murrieta. Dialética do Sabor: alimentaÇão, eCologia e Vida Cotidiana

MURRIETA, R. S. S., DUFOUR, D., SIQUEIRA, S.

1999

"Food Consumption and Subsistence in Three Caboclo Populations on Marajo Island, Amazônia, Brazil”, Human Ecology, vol. 27(3): 455-75.

NETTING, R. M.

1993 Smalholders, Householders, Stanford, Stanford University Press.

NETTING, R. M., WILK, R. W., ARNOULD, E. J.

1984

"Introduction", in Households, Berkeley, University of California Press.

NUGENT, S.

1993

"Amazonian Caboclo Society: An Essay on Invisibility and Peasant Economy”, Providence, Berg Publishers.

PACE, R.

1998

Amazon Tomn: Gumpa Revisited, Boulder/London, Lynne Rienner Publishers.

PARKER, E.

$1985 \mathrm{a}$

The Amazon Caboclo: an Introduction and Overview, in PARKER, E. (ed.), The Amazon Caboclo: Historical and Contemporary Perspectives, Studies in Third World Societies, Virginia, vol. 32, pp. xvii-li.

1985b "Caboclization: Transformation of the Amerindian in Amazonia, 16151800", in PARKER, E. (ed.), The Amazon Caboclo: Historical and Contemporary Perspectives, Studies in Third World Societies, vol. 32, Virginia, pp. xvii-li.

ROCHA, Y. R., YUYAMA, L. K. O., NASCIMENTO, O. P.

1993

"Perfil nuticional de pré-escolares e escolares residentes em Palmeiras do Javari, AM", Acta Amazônica, vol. 23(1): 9-14.

RODRIGUES, A. G.

2000 O significado da Reima, trabalho apresentado na XXII reunião da Associação Brasileira de Antropologia, Brasília, D. F.

ROLLS, E. T.

"Neural processing underlying food selection", in MACBETH, H. (ed.), Food Preferences and Tast, Oxford, Berghahn Books. 
Revista de Antropologia, São Paulo, USP, 2001, v. 44 nº 2.

ROOSEVELT, A. C.

1980

Parmana, Prehistoric Maize and Manioc Subsistence Along the Amazon and Orinoco, New York, Academic Press.

ROSS, J. K.

1978

"The Evolution of Amazonian Peasantry", Journal of Latin American Studies, vol. 10(2): 193-218.

ROZIN, P.

1987

"Psychobiological perspectives on food preferences and avoidances", in HARRIS, M. \& ROSS, E. (eds.), Food and Evolution: Toward a theory of Human Food Habits, Philadelphia, Temple University Press.

SANTOS, R. V. \& COIMBRA JR., C. E. A.

1994

"Contato, mudanças sócio-econômicas e a bioantropologia dos TupiMondé da Amazônia Brasileira", in Saúde epovos indígenas, Rio de Janeiro, Fiocruz, pp. 189-213.

1998

"On the (un) natural history of the Tupi Mondé Indians: Bioanthropology and change in the Brazilian Amazon", in GOODMAN, A. H. \& LEATHERMAN, T. (eds.), Building a New Biocultural Synthesis: PoliticalEconomic Perspectives on Human Biology, Ann Arbor, The University of Michigan Press.

\section{SCHVELBUSCH, W.}

1992 Tastes of Paradise, New York, Vintage Books.

SILVA, H. P., CREWS, D. E., NEVES, W. A.

"Subsistence Patterns and Blood Pressure Variation in Two Rural Caboclo Communities of Marajó Island, Pará, Brazil”, American Journal of Human Biology, vol. 7: 535-42.

SIQUEIRA, A. D.

1997

The Ecology of Food and Nutrition: patterns of land use and nutritional status among caboclo populations on Marajó Island, Pará, Brazil, Unpublished Ph.D. Dissertation, Department of Anthropology, Indiana University, Bloomington, Indiana. 
Rui S. S. Murrieta. DialÉTica do Sabor: alimentaÇão, eCologia E Vida Cotidiana

SLATER, C.

1994

The Dance of the Dolphin, Chicago, University of Chicago Press.

SMITH, N.

1981 Man, Fishes and the Amazon, NewYork, Columbia University Press.

WAGLEY, C.

1988 Uma comunidade amazônica, São Paulo, Edusp.

WEINSTEIN, B.

1991 A borracha na Amazônia: expansão e decadência, São Paulo, Hucitec/Edusp.

WILK, R.

1989 The Household Economy, Boulder, Westview.

WINKLERPRINS, A.

1999 Between the Floods: Soils and Agriculture on the Lower Amazon Floodplain, Brazil, Unpublished Ph.D. Dissertation, Geography Department, University of Wisconsin, Madison. 
Revista de Antropologia, São Paulo, USP, 2001, v. 44 nº 2.

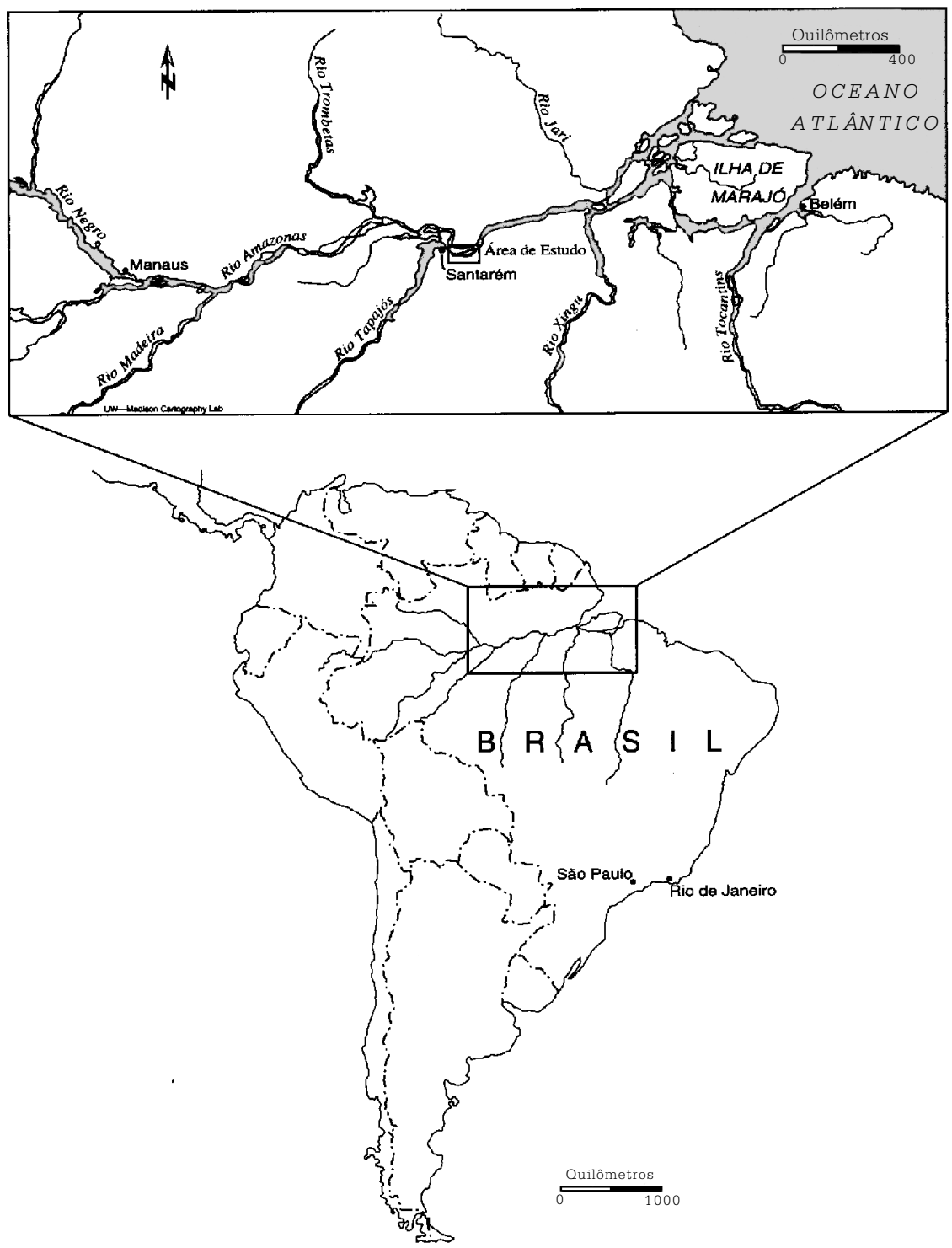

Localização da Área de Estudo 
Rui S. S. Murrieta. DialÉTica do Sabor: alimentaÇão, eCologia E Vida Cotidiana

Tabela 1: Contribuição total (em \%) e média dos itens alimentares consumidos nas unidades domésticas em São Benedito e Aracampina em termos de energia e proteína

\begin{tabular}{|c|c|c|c|c|c|c|}
\hline & \multicolumn{2}{|c|}{ Aracampina } & \multicolumn{2}{|c|}{ São Benedito } & \multicolumn{2}{|c|}{ média } \\
\hline itens alimentares & energia $\%$ & proteína \% & energia $\%$ & proteína $\%$ & energia $\%$ & proteína $\%$ \\
\hline açúcar & 11.0 & 0 & 11.5 & 0 & 11.8 & 0 \\
\hline carne de galinha & 2.0 & 6.4 & 4.2 & 8.5 & 3.1 & 7.4 \\
\hline $\begin{array}{l}\text { carne bovina, suína } \\
\text { e de caça }\end{array}$ & 0.6 & 1.9 & 1.6 & 4.3 & 1.1 & 3.1 \\
\hline peixe & 17.5 & 54.3 & 26.0 & 64.1 & 21.7 & 59.2 \\
\hline mandioca e derivados & 34.0 & 5.4 & 25.2 & 1.9 & 29.6 & 3.7 \\
\hline $\begin{array}{l}\text { cereais (arroz, trigo } \\
\text { e milho) }\end{array}$ & 8.2 & 5.4 & 10.5 & 5.4 & 9.4 & 5.4 \\
\hline feijão & 1.5 & 2.5 & 1.7 & 3.1 & 1.6 & 2.8 \\
\hline frutas & 3.4 & 2.9 & 1.5 & 0.7 & 2.4 & 1.8 \\
\hline laticínios & 7.3 & 11.6 & 2.7 & 3.1 & 5.0 & 7.3 \\
\hline óleo de cozinha & 4.2 & 0 & 2.6 & 0 & 3.4 & 0 \\
\hline outros & 9.3 & 9.6 & 12.5 & 9.9 & 10.9 & 9.3 \\
\hline
\end{tabular}


Revista de Antropologia, São Paulo, USP, 2001, v. 44 nº 2.

Tabela 2: Contribuição sazonal de itens alimentares para os consumos de energia e proteína (\%) em Aracampina e São Benedito

\begin{tabular}{|c|c|c|c|c|c|c|c|c|}
\hline \multirow[b]{3}{*}{ itens alimentares } & \multicolumn{4}{|c|}{ Aracampina } & \multicolumn{4}{|c|}{ São Benedito } \\
\hline & \multicolumn{2}{|c|}{ estação seca } & \multicolumn{2}{|c|}{ estação chuvosa } & \multicolumn{2}{|c|}{ estação seca } & \multicolumn{2}{|c|}{ estação chuvosa } \\
\hline & $\mathrm{E} \%$ & $\mathrm{P} \%$ & $\mathrm{E} \%$ & $\mathrm{P} \%$ & $\mathrm{E} \%$ & $\mathrm{P} \%$ & E\% & $\mathrm{P} \%$ \\
\hline açúcar & 9.2 & 0 & 12.7 & 0 & 10.1 & 0 & 12.8 & 0 \\
\hline carne de frango & 0.8 & 2.2 & 5.3 & 10.8 & 0 & 0 & 8.4 & 17.0 \\
\hline $\begin{array}{l}\text { carne bovina, suína } \\
\text { e de caça }\end{array}$ & 0.4 & 0.9 & 1.0 & 3.6 & 1.1 & 3.0 & 2.2 & 5.7 \\
\hline peixe & 16.2 & 58.2 & 19.0 & 50.2 & 29.5 & 73.3 & 22.4 & 55.0 \\
\hline mandioca e derivados & 34.0 & 3.6 & 28.6 & 7.3 & 22.9 & 1.6 & 27.6 & 2.2 \\
\hline $\begin{array}{l}\text { cereais (arroz, trigo } \\
\text { e milho) }\end{array}$ & 10.5 & 6.4 & 5.2 & 3.8 & 14.7 & 6.4 & 6.3 & 4.5 \\
\hline feijão & 2.4 & 3.3 & 0.5 & 0.2 & 2.4 & 3.6 & 1.1 & 2.6 \\
\hline frutas & 1.1 & 0.4 & 5.44 & 3.1 & 0.5 & 0.3 & 2.5 & 1.0 \\
\hline laticínios & 11.0 & 15.1 & 2.9 & 6.5 & 3.3 & 3.0 & 2.1 & 3.2 \\
\hline óleo de cozinha & 3.5 & 0 & 4.0 & 0 & 1.9 & 0 & 3.4 & 0 \\
\hline outros & 10.9 & 9.9 & 16.3 & 14.5 & 13.5 & 9.8 & 11.2 & 9.8 \\
\hline
\end{tabular}




\begin{abstract}
Few aspects of human life are so deeply connected with basic survival and, at the same time, with symbolic and socially constructed elements than food. This paper presents and analyses data on food choice among the inhabitants of Ituqui Island, Lower Amazon, Pará state. The staples on Ituqui Island are represented by the traditional Amazonian combination of fish and farinha (manioc flour). It is also apparent an effort of diversification concomitantly to ways of cotemporizing the continuities of everyday life with social constructions of class, which appear to shape the processes of food choice and consumption. Even though, there is not a positive correlation between high status foods and the staples. In addition, many discursive ways of representing food appear to contradict the social practices, which are characterized by flexibility and negotiation of sociopolitical domains. Such domains include the household and community micro-politics as well as broader political-economy contexts of regional and transnational markets. Thus, through these mediating qualities potential forces of change and conflict are accommodated. In conclusion, the ways we de-codify our physical experiences and biological needs engage into a dialectical relation with our social desires and habitual structures, which can only be understood when the contextual conditions of the moment of action are contemplated.
\end{abstract}

KEY-WORDS: food, caboclos, Amazon, habitus, ecology.

Recebido em maio de 2001. 